\title{
Konflik Sosial Nelayan Pesisir Desa Teluk Bakau Kecamatan Gunung Kijang Kabupaten Bintan Provinsi Kepulauan Riau
}

\author{
Ferizone $^{1}$, Endri Bagus Prastiyo² \\ Dosen Administrasi Publik, Sekolah Tinggi dan Ilmu Sosial dan IImu Politik Raja Haji \\ Email: ferizone@stisipolrajahaji.ac.id \\ ${ }^{2}$ Dosen Sosiologi, Sekolah Tinggi dan IImu Sosial dan Ilmu Politik Raja Haji \\ Email : endribagus@stisipolrajahaji.ac.id
}

\begin{abstract}
Social conflict occurs because fishermen coastal due to the construction of coastal use space that may lead to conflict the fishermen.Space activities to earn fisherman disturbed the land for the coastal ekspolitasi activities by private. This report is written with deep relating to have the isue-isue that develops mangrove of Village the gulf of activities relating to the increasing company from tourism sector. Informants research is the parties involved in conflict a total of 14 people, head of the RW 002 village Teluk Bakau was used as a key informants. Research methods that were used qualitative descriptive is research .Results in this research is that there is a manifest conflict between the community fishermen with private party, latent conflict between the community fishermen and officials the village administration Teluk Bakau, and conflicts of agrarian affairs or the race for coastal areas get most fishermen with the community who live outside the village Teluk Bakau.
\end{abstract}

Keywords : Social conflict; Coastal Fishermen; Capture Area

\begin{abstract}
Abstrak. Konflik sosial nelayan pesisir yang terjadi disebabkan karena adanya pembangunan yang memanfaatkan ruang pesisir pantai yang dapat memicu konflik di masyarakat nelayan. Ruang aktifitas nelayan untuk mencari nafkah menjadi terganggu karena semakin maraknya kegiatan ekspolitasi lahan pesisir pantai oleh pihak swasta. Penelitian ini dilakukan dengan melakukan pendekatan yang mendalam terkait dengan isueisue yang berkembang didesa teluk bakau terkait dengan semakin meningkatnya aktifitas perusahaan di sektor pariwisata. Informan penelitian merupakan pihak-pihak yang terlibat dalam konflik berjumlah 14 orang, sedangkan ketua RW 002 Desa Teluk Bakau dijadikan sebagai informan kunci. Metode penelitian yang digunakan adalah penelitian deskriptif kualitatif. Hasil dalam penelitian ini adalah adanya konflik manifest antara masyarakat nelayan dengan pihak swasta, konflik laten antara masyarakat nelayan dengan pihak Aparat Pemerintah Desa Teluk Bakau, dan konflik agraria atau perebutan wilayah tangkap antara nelayan pesisir dengan masyarakat yang berdomisili di luar Desa Teluk Bakau.
\end{abstract}

Kata Kunci : Konflik Sosial; Nelayan Pesisir; Wilayah Tangkap

\section{PENDAHULUAN}

Munculnya pembangunan usaha akomodasi pariwisata yang mengeksploitasi wilayah pesisir pantai Desa Teluk Bakau menyebabkan semakin sempitnya wilayah tangkap nelayan pesisir yang juga mempengaruhi hasil tangkapan nelayan pesisir yang semakin menurun yang kemudian dapat melatarbelakangi munculnya konflik. Razak (2017), dalam bukunya yang berjudul "Perkembangan Teori-Teori Sosial", konflik sosial di bagi menjadi dua yaitu konflik vertikal dan horizontal. Konflik vertikal merupakan konflik antar komponen masyarakat di dalam satu struktur yang memiliki hirarki. 
Novri Susan (2009) konflik memperlihatkan berbagai individu, kelompok, organisasi, membawa angka kepentingannya masing-masing. Kepentingan bisa berwujud dalam bentuk kepentingan ekonomis maupun politis. Sementara itu Menurut Hendrajaya, (2015), pemerintah berkolaborasi dengan pemodal dalam upaya eksploitasi sumber daya alam untuk kepentingan pribadi.

Menurut Kusnadi, (2002) sumber daya ekonomi lingkungan yang menjadi basis kelangsungan hidup dan sebagai satuan sosial, masyarakat nelayan memiliki identitas kebudayaan yang berbeda dengan satuan-satuan sosial lainnya. Aktifitas nelayan Desa Teluk bakau mulai mengalami perubahan karena terjadinya konversi lahan pesisir menjadi daerah komersil wisata. Menurut Tejoyuwono (2006:1) pengalihan fungsi lahan atau lazimnya disebut sebagai konversi lahan adalah perubahan fungsi sebagian atau seluruh kawasan lahan dari fungsinya semula (seperti yang direncanakan) menjadi fungsi lain yang menjadi dampak negatif (masalah) terhadap lingkungan dan potensi lahan itu sendiri, sejalan dengan itu Furi (2007), menjelaskan bahwa konversi lahan atau alih fungsi lahan yang terjadi mengubah status kepemilikan lahan dan penguasaan lahan. Perubahan dalam penguasaan lahan di pedesaan membawa implikasi bagi perubahan pendapatan dan kesempatan kerja masyarakat yang menjadi indikator kesejahteraan masyarakat desa.

Pihak swasta yaitu Bintan Agro Beach Resort karna dianggap menyulitkan mereka dalam melakukan aktivitasnya yaitu menangkap ikan dan memasang bubu ketam di wilayah pesisir pantai, ditambah lagi aktivitas pembangungan villa dan jembatan tersebut menyebabkan terjadinya kerusakan pada alat tangkap mereka seperti jaring ikan dan bubu ketam dan juga menyebabkan karang-karang ikan menjadi rusak. Kedua, masyarakat nelayan pesisir meminta kepada pihak swasta agar di sediakan akses jalan untuk menuju kelaut tempat penambatan sampan dan boat yang mereka gunakan untuk melaut mengingat sepanjang pesisir pantai di Desa Teluk Bakau sudah dibangun pagar beton oleh pihak swasta.

Berikut perkembangan pembangunan usaha akomodasi pariwisata yang di bangun diatas lahan pesisir pantai di Desa Teluk Bakau dari tahun 2014-2018:

Tabel 1.2

Jumlah Pembangunan Usaha Akomodasi Pariwisata Dari Tahun 2014-2018 Di Desa Teluk Bakau

\begin{tabular}{|c|c|c|c|c|c|c|c|}
\hline \multirow[t]{2}{*}{ NO } & \multirow[t]{2}{*}{ NAMA USAHA } & \multicolumn{5}{|c|}{ TAHUN } & \multirow[t]{2}{*}{ TOTAL } \\
\hline & & 2014 & 2015 & 2016 & 2017 & 2018 & \\
\hline 1 & Bintan Agro Beach Resort & 50 & 30 & 70 & 85 & 15 & 250 Unit \\
\hline 2 & Bintan Spa Villa & 11 & 2 & 1 & 5 & 6 & 25 Unit \\
\hline 3 & Kelong Pancing Helly & 7 & 4 & 5 & 3 & 4 & 23 Unit \\
\hline 4 & Pearl Beach Resort & 10 & 3 & 2 & 1 & 4 & 22 Unit \\
\hline
\end{tabular}

Sumber: Data Desa Teluk Bakau Tahun 2018

Data diatas memberikan gambaran bahwa pembangunan usaha akomodasi pariwisata yang mengeksploitasikan alih fungsi lahan pesisir pantai Desa Teluk Bakau semakin gencar dilakukan oleh pihak pengembang pariwisata sehingga masyarakat nelayan pesisir Desa Teluk Bakau berasumsi bahwa untuk kedepannya mereka tidak bisa lagi menjalankan rutinitas mereka sebagai nelayan, karena sepanjang daerah pesisir pantai sudah di bangun usaha akomodasi pariwisata, serta minimnya sumber daya manusia masyarakat nelayan pesisir yang ada di Desa Teluk Bakau juga masih belum mampu bersaing dalam sektor pariwisata baik dalam skala kecil, menengah, maupun besar, yang kemudian hal ini melatarbelakangi munculnya konflik sosial. Konflik sosial tersebut melibatkan masyarakat nelayan pesisir Konflik sosial masyarakat nelayan pesisir di Desa Teluk Bakau cukup 
beralasan, mengingat konflik yang terjadi berkaitan dengan adanya perbedaan kepentingan dan adanya kondisi sumberdaya yang terbatas sehingga menjadi bahan rebutan yang menyebabkan konflik. Meskipun saat ini pertentangan yang terjadi masih bersifat non fisik akan tetapi tidak menutup kemungkinan berkembang menjadi benturan fisik atau kekerasan.

\section{METODE PENELITIAN}

Metode pengkajian dalam penelitian ini adalah metode kualitatif, Penelitian ini dilakukan di Desa Teluk Bakau, Kecamatan Gunung Kijang, Kabupaten Bintan. Populasi dalam penelitian ini adalah jumlah seluruh masyarakat nelayan yang berada di Desa Teluk Bakau Kecamatan Gunung Kijang Kabupaten Bintan Kepulauan Riau sebanyak 144 orang. Menurut Sugiyono (2008), purposive sampling yaitu teknik pengambilan sampel sumber data yang dipilih dengan pertimbangan dan tujuan tertentu. Jadi dalam penelitian ini sampelnya adalah 14 orang dengan kriteria yang ada yaitu, Nelayan pesisir, Tokoh Masyarakat, Aparat Pemerintah Desa dan Pihak Korporasi.

\section{HASIL DAN PEMBAHASAN}

\section{A. Konflik Manifest Antara Nelayan Dengan Pihak Perusahaan}

Menurut Sastrawidjaya, (2002) komunitas nelayan adalah kelompok orang yang bermata pencaharian hasil laut dan tinggal di desa-desa atau pesisir. Hasil penelitian dapat ditemukan faktafakta dilpangan bahwasannya konflik yang begitu nyata dan Nampak kepermukaan adalah konflik antara nelayan dengan pihak korporasi yang membuka bisnis wisata di wilayah mereka. Konflik ini mulai muncul setelah banyak dari usaha pariwisata yang mulai menutup dan membatasi akses masyarakat lokal dalam menjalankan aktifitas nelayan karena dianggap telah mengganggu kenyamanan pengunjung yang data ke lokasi usaha wisata. Larangan-larangan ini tentu mendapat reaksi yang tidak baik dari masayrakat tempatan yang sejak lama berprofesi sebagai nelayan dan mencari nafkah di pesisir pantai Desa Teluk Bakau.

Berikut wawancara dengan tokoh masyarakat berinsial RAH Usia 49 Tahun mengenai dominasi lahan pesisir oleh pihak swasta.

Meningkatnya aktivitas pembangunan wisata setiap tahun yang memanfaatkan ruang pesisir pantai di Desa Teluk Bakau dalam jumlah yang besar jelas, menyebabkan semakin sempitnya wilayah tangkap nelayan. Kalau pembangunan itu terus meningkat setiap tahun bukan hanya nelayan pesisir yang susah tapi seluruh masyarakat yang bukan nelayan pun susah mau menuju pantai. Kami psudah pernah mengajaukan protes kepada aparat desa untuk meminta jalan namun tidak ada hasil, bahkan kami juga sempat memblokade akses masuk tempat wisata sebagai bentuk protes tapi kami justru diancam hendak dilaporkan ke pihak kepolisian. Kami sudah bingung tidak tau harus bagaimana lagi (Wawancara, dengan tokoh masyarakat Desa Teluk Bakau).

Dari hasil wawancara di atas dengan informan, informan menyebutkan bahwa dari hasil pendapatan para nelayan pesisir di Desa Teluk Bakau, dipengaruhi oleh ruang lingkup wilayah tangkap. Selain itu, para masyarakat nelayan juga mengeluh dengan kondisi mereka yang sekarang ini. Munculnya pembangunan usaha akomodasi pariwisata yang semakin meningkat setiap tahunnya di wilayah pesisir pantai Desa Teluk Bakau menyebabkan semakin sempitnya ruang tangkap nelayan, 
sehingga mempengaruhi hasil tangkapan nelayan yang kemudian berdampak pada kehidupan sosial ekonomi mereka.

Situasi tersebut sesuai dengan pendapat dari informan yang berinisial Bapak SR berusia 40 Tahun, yang diwawancarai mengenai dominasi lahan pesisir oleh pihak swasta yang berdampak pada perekonomian masyarakat nelayan pesisir yang menggantungkan hidupnya pada sumber daya pesisir.

Kami sebagai nelayan pesisir sekarang ini kebingungan untuk mencari lokasi menangkap ikan sama lokasi untuk memasang bubu ketam, dulu sebelum ada pembangunan hotel di wilyah tangkap nelayan, kami bisa pasang bubu ketam itu sampai lima puluh buah bahkan bisa sampai seratus buah bubu ketam di wilayah pesisir pantai kami ini, tapi sekarang jangan kan mau pasang segitu, mau pasang dua puluh buah bubu ketam saja sekarang ini sudah susah karna lokasi tangkap kami sudah semakin sempit. nelayan pesisir di Desa Teluk Bakau ini merasakan dampak dari pembangunan hotel terutama dampak pada perekonomian kami yang semakin menurun. Kami ini hanya orang kecil, jika terlalu banyak protes dan melawan justru kami bisa mendapat masalah (Wawancara, dengan masyarakat nelayan pesisir Desa Teluk Bakau).

Berikut wawancara dengan informan berinisial Bpk AF Usia 44 Tahun mengenai konflik antara masyarakat nelayan pesisir dengan pihak swasta.

Kami sebagai nelayan di Desa Teluk Baku ini jelas menolak dengan pembangunan hotelhetel di tempat kami menjaring ikan, karna aktivitas pembangunan hotel itu wilayah tangkap kami jadi sempit merusak karang-karang ikan, aktivitas wisatawan yang bermain water spot membuat ikan takut berkumpul jadi ini kan merugikan ekonomi kami, sebagai nelayan macam mana kami mau cari makan, jadi tahun 2017 lalu kami sepakat dengan nelayan pesisir di Desa Teluk Bakau ini mengadakan aksi ke pihak agro resort untuk menuntut agar mereka menghentikan aktivitas pembangunan hotel di wilayah tangkap kami. Tapi hasilnya sangat mengecewakan karena mereka sudah mendapatkan Hak Izin Usaha dari pemerintah, jadi pembangunan itu tidak bisa di hentikan. Ditambah lagi adanya penambangan pasir ilegal itu lebih membuat keadaan kami semakin parah, limbahnya menyebabkan laut kami yang tersisa ini menjadi tercemar. Nasib kami ini ibaratnya sudah jatuh ditimpa tangga. (wawancara dengan masyarakat nelayan pesisir Desa Teluk Bakau).

Dari hasil wawancara dengan informan, informan mengatakan bahwa, munculnya sikap penolakan masyarakat nelayan pesisir terhadap pembangunan usaha akomodasi pariwisata menurut mereka pembangunan usaha akomodasi pariwisata yang semakin meningkat setiap tahunnya di wilayah pesisir pantai Desa Teluk Bakau menyebabkan semakin sempitnya ruang tangkap mereka, sehingga mempengaruhi hasil tangkapan nelayan yang kemudian berdampak pada kehidupan sosial ekonomi mereka. Sehingga hal tersebut memicu munculnya konflik yang tampak dan sangat berpengaruh besar terhadap masyarakat.

Konflik yang terjadi antara masyarakat nelayan pesisir terhadap pihak swasta sama halnya dengan konflik yang terjadi antara masyarakat nelayan pesisir Desa Teluk Bakau dengan Aparat Pemerintah Desa yaitu adanya perbedaan kepentingan dalam penggunaan lahan pesisir. Bagi pihak swasta lahan pesisir Desa Teluk Bakau adalah lahan yang memiliki potensi untuk meningkatkan nilai investasi namun bagi masyarakat nelayan pesisir lahan tersebut adalah tempat dimana mereka biasa melakukan aktivitas mereka dalam memenuhi kebutuhan ekonomis mereka. Kondisi inilah yang kemudian memicu terjadinya konflik. Konflik yang terjadi antara kelompok masyarakat nelayan pesisir dengan pihak swasta adalah konflik manifest. Bentuk dari konflik manifest itu sendiri yaitu pergerakan masyarakat nelayan pesisir dalam bentuk aksi demontrasi terhadap pihak swasta yang bertujuan untuk menuntut agar aktivitas pembangunan usaha akomodasi pariwisata segera dihentikan karena menurut mereka pembangunan usaha akomodasi pariwisata yang dibangun di 
wilayah pesisir pantai Desa Teluk Bakau mengancam eksistensi mereka yang beraktivitas sebagai nelayan.

Dari hasil data dapat dilihat bahwa masyarakat nelayan pesisir Desa Teluk Bakau merasakan dampak dari pembangunan usaha akomodasi pariwisata yang mengeksploitasi lahan pesisir pantai Desa Teluk Bakau. Hal ini membuktikan bahwa masyarakat nelayan Desa Teluk Bakau merasakan dampak ekonomis yang semakin menurun dengan kehadiran aktivitas pembangunan pariwisata. Munculnya pembangunan usaha akomodasi pariwisata di Desa Teluk Bakau saat ini menyisakan penderitaan bagi masyarakat yang sangat mengandalkan perairan pesisir sebagai tempat untuk kelangsungan hidup. Kondisi tersebut sangat berpengaruh terhadap semakin menurunya hasil tangkapan yang diperoleh. Akan tetapi, meskipun demikian pekerjaan sebagai nelayan tetap dilakoni mengingat tidak ada pekerjaan lain yang mereka dapat lakukan di luar ketrampilan yang dimilikinya. Pekerjaan sebagai nelayan bagi mereka sudah menjadi bagian yang tidak dapat dipisahkan dari kehidupannya, sehingga apapun yang terjadi sudah merupakan kodrat yang mesti dilalui untuk dapat menyambung hidup diri dan keluarganya.

Selain itu, keterdesakan juga tampak dari semakin sempitnya wilayah tangkap nelayan yang biasa digunakan nelayan untuk menjalankan aktivitasnya menangkap ikan. Kondisi tersebut disebabkan karena tempat yang biasanya akrab dengan nelayan sekarang sudah banyak dimanfaakan oleh pihak swasta untuk berbagai kepentingan yang lebih berorientasi pada kepentingan ekonomi seperti villa, hotel, restoran, water sport, dan usaha lainnya. Pemanfaatan tersebut di satu sisi memang akan menguntungkan bagi pelaku usaha seiring dengan mulai banyaknya wisatawan domestik maupun mancanegara yang berkunjung ke daerah tersebut. Akan tetapi di sisi lainnya, para nelayan merasa dirugikan karena kehilangan wilayah tangkap mereka. Kedepannya jika masih seperti ini bukan tidak mungkin gelombang konflik antara masyarakat nelayan dengan pihak korporasi akan semakin membesar karena sudah tidak terkendalinya lagi situasi yang selalu merugikan dan menyudutkan masayrakat nelayan.

\section{B. Menurunnya Kualitas Lingkungan Pesisir}

Berikut wawancara dengan informan berinisial Bapak SM Usia 35 Tahun tentang menurunnya kualitas lingkungan pesisir, yaitu sebagai berikut:

Keadaan laut sekarang berbeda dengan dulu, karena aktivitas pembangunan hotel, villa dan restoran yang dibangun diatas laut pesisir pantai Desa Teluk Bakau saat ini menyebabkan karangkarang ikan rusak, sarang ketam rusak, daun setu juga rusak. Sekarang orang mau cari gamat sama kerang kalau mau banyak dapat ya harus nyelam di suak laut pesisir. Itu semua karena sarangsarang hewan laut sudah terganggu akibat aktivitas pembangunan. Selain itu aktivitas wisatawan yang bermain water spot, suara mesin dari berbagai jenis angkutan, seperti boat, kapal wisata, perahu, mengganggu kelompok ikan yang berkumpul di wilayah laut pesisir Desa Teluk Bakau tempat biasa kami menangkap ikan, akhirnya kelompok ikan yang berkumpul itu lari jauh ke laut. (wawancara dengan nelayan pesisir Desa Teluk Bakau).

Berdasarkan hasil wawancara diatas dengan informan, informan menyebutkan bahwa pembangunan usaha akomodasi pariwisata di wilayah pesisir pantai Desa Teluk Bakau menyebabkan kerusakan ekosistem laut. Situasi ini juga yang menjadi faktor menurunnya produktivitas hasil tangkapan mereka karena kerusakan ekosistem laut dan pesisir yang telah menyulitkan para komunitas nelayan pesisir Desa Teluk Bakau dalam memperoleh pendapatan yang stabil. Adanya pembangunan usaha akomodasi pariwisata di Desa Teluk Bakau saat ini lebih banyak menyisakan kesulitan yang banyak dirasakan terutama oleh masyarakat nelayan Desa Teluk Bakau yang mengggantungkan hidupnya dari hasil penangkapan ikan di perairan pesisir. Ekosistem laut yang sebelumnya sangat dekat dengan kehidupan nelayan dan menjadi sumber perikanan jumlahnya sudah semakin menyusut. Menyusutnya ekosistem laut di wilayah pesisir Desa Teluk Bakau 
berpengaruh segnifikan terhadap sumber perikanan yang diperoleh oleh masyarakat nelayan pesisir desa Teluk Bakau. Bahkan jenis hewan laut seperti ikan bebulus yang biasa ditemukan di perairan pesisir Desa Teluk Bakau keberadaannya semakin langka.

Dari hasil wawancara juga menjelaskan bahwasanya Hak Izin Usaha yang diberikan Pemerintah kepada pihak swasta menyebabkan keadaan mereka sebagai nelayan semakin terpuruk. Kerusakan lingkungan pesisir laut di Desa Teluk Bakau seperti kerusakan karang ikan akibat dari pembangunan usaha akomodasi pariwisata, serta aktivitas wisatawan yang membuat komunitas ikan yang berada di wilayah pesisir menjadi takut, akan berdampak pada hasil tangkapan mereka. Menurut mereka ketersedian lapangan kerja yang di programkan oleh pihak swasta buakanlah sebuah solusi yang tepat bagi kehidupan sosial ekonomi mereka sebagai masyarakat nelayan, karena mereka sudah terbiasa bekerja sebagai nelayan atau menangkap ikan di laut, menurut mereka jangankan untuk bekerja sebagai karyawan di hotel-hotel yang ada di desa Teluk Bakau, untuk bekerja sebagai buruh bangunan saja tidak ada yang mau, hal ini disebabkan karena aktivitas sebagai nelayan sudah mereka tekuni sejak lama yaitu sejak mereka muda hingga saat ini.

Dari penjelasan diatas dapat diketahui bahwasanya masuknya rencana investasi pariwisata ke daerah Desa Teluk Bakau dalam bentuk usaha akomodasi pariwisata berimbas terhadap perairan di sekitarnya. Kondisi perairan pantai menjadi hiruk pikuk oleh beragam kegiatan wisata dan peralatan pendukungnya. Keberagaman bentuk aktivitas yang dilakukan dengan memanfaatkan perairan pantai sebagai ruang usaha, sebenarnya sangat merugikan nelayan yang biasa menggunakannya sebagai lahan dalam menggeluti hidup sehari-hari. Hiruk pikuk suara mesin dari berbagai jenis angkutan, seperti boat, kapal wisata, perahu, aktivitas wisatasan yang bermain water spot dan jenis lainnya telah mengusik keberadaan ikan dan biota laut lain yang hidup di habitatnya. Para nelayan juga kerap kali merasa kurang nyaman atas pemanfaatan perairan sekitar sebagai tempat beragam kepentingan. Dalam melakukan aktivitas melaut adakalanya alat tangkap milik nelayan berupa jaring ikan yang di bentang di laut pesisir di langgar oleh karyawan hotel yang membawa wisatawan snorkeling sehingga menyebabkan kerusakan pada alat tangkap mereka. Akibat kejadian tersebut masyarakat nelayan melakukan resistensi dalam bentuk aksi demontrasi ke pihak swasta menuntut pertanggung jawaban atas peristiwa yang menerpa mereka.

\section{Sikap Nelayan Pesisir Terhadap Pihak Swasta}

Wilayah pesisir adalah suatu wilayah peralihan antara ekosistem daratan dan laut. Hampir seluruh bagian garis pantai di Desa Teluk Bakau Kecamatan Gunung Kijang Kabupaten Bintan Kepulauan Riau memiliki potensi wisata untuk dikembangkan. Potensi wisata di Desa Teluk Bakau menarik perhatian para pengembang usaha untuk membangun usaha akomodasi pariwisata di wilayah pesisir pantai Desa Teluk Bakau yang kemudian memberikan dampak pada lingkungan dan kehidupan sosial masyarakat setempat.

Berikut wawancara dengan informan berinisial UN Usia 50 Tahun, mengenai tentang sikap masyarakat nelayan pesisir terhadap pihak swasta.

Sebenarnya kami setuju dengan pembangunan hotel di Desa Teluk Bakau ini, Desa kami jadi maju dan jadi Desa wisata, peluang lapangan kerja untuk anak-anak kami terbuka lebar, Desa kami pun ramai di datangi orang-orang luar. Cuma kenyataannya kan sekarang lain, hotel-hotel yang dibangun merusak karang-karang ikan, merusak tempat tinggal ketam, tumbuhan laut pun rusak, laut pun makin sempit banyak lah dampaknya bagi nelayan. Saya juga merasakan tapi kalau macam saya ini sudah tua, anak-anak pun sudah besar semua dan sudah pada menikah, yang saya nafkahi sekarang hanya istri saya, jadi cukuplah dengan hasil pendapatan saya sekarang ini. (wawancara dengan masyarakat nelayan pesisir Desa Teluk Bakau) 
Berdasarkan hasil wawancara informan menyebutkan sikap penolakan masyarakat nelayan pesisir Desa Teluk Bakau itu muncul karena pembangunan usaha akomodasi pariwisata di wilayah pesisir pantai Desa Teluk Bakau memberikan dampak pada lingkungan laut pesisir yang mempengaruhi penghasilan mereka. Pesatnya pembangunan yang dilakukan oleh pihak pengembang usaha yang tidak memperhatikan prinsip-prinsip ekologi tidak hanya menyebabkan kerusakan pada ekosistem laut tetapi juga menyebabkan semakin sempitnya ruang tangkap nelayan pesisir. Menurut kelompok masyarakat nelayan pesisir pembangunan usaha akomodasi pariwisata secara besar-besaran yang menyebabkan kerusakan lingkungan laut pesisir Desa Teluk Bakau adalah suatu ancaman bagi kehidupan sosial ekonomi mereka, asumsi inilah yang kemudian terus berkembang di lingkungan kelompok masyarakat nelayan pesisir Desa Teluk bakau hingga muncul sikap penolakan terhadap pembangunan usaha akomodasi pariwisata yang dilakukan oleh pihak swasta.

\section{Konflik Antara Masyarakat Nelayan Pesisir Dengan Pihak Aparat Pemerintah Desa}

Berikut wawancara dengan tokoh masyarakat Desa Teluk Bakau berinisial Bapak RAH Usia 49 Tahun wawancara mengenai konflik anatara masyarakat nelayan pesisir dengan pihak Aparat Pemerintah Desa yaitu sebagai berikut :

Tahun 2016 lalu, saya selaku ketua Rw 002 di Desa Teluk Bakau, diundang untuk menghadiri acara sosialisasi yang di hadiri oleh kepala desa, pihak swasta, ketua Rt yang ada di Desa Teluk Bakau ini, membahas masalah Hak Izin Usaha penambahan hotel yang akan dibangun di wilayah pesisir laut Rt 003 Rw 002 Desa Teluk Bakau, memang dalam acara sosialisasi itu tidak ada membahas masalah AMDAL, tapi disitu kita membahas tentang kesepakatan bahwa pihak swasta berjanji akan mengutamakan masyarakat lokal untuk mendapatkan lapangan pekerjaan sekitar 30\% masyarakat lokal akan dilibatkan, serta dalam proses pembangunan usaha akomodasi pariwisata pihak swasta akan melibatkan pemborong lokal yang ada di Desa Teluk Bakau. (wawancara dengan tokoh masyarakat Desa Teluk Bakau)

Berdasarkan hasil wawancara bahwa informan menyebutkan pada tahun 2016 lalu diadakan sosialisasi yang melibatkan Aparat Pemerintah Desa beserta dengan perangkatnya, dan pihak swasta membahas masalah Hak Izin Usaha penambahan pembangunan usaha akomodasi pariwisata yang akan di bangun di wilayah pesisir Desa Teluk Bakau tepatnya di Rt 003 Rw 002 . Menurut keterangan dari tokoh masyarakat Desa Teluk Bakau, dalam sosialisasi tersebut tidak ada menyinggung terkait AMDAL. Namun, sosialisasi yang berlangsung lebih membahas tentang kesepakatan penyediaan lapangan pekerjaan untuk masyarakat lokal sebanyak $30 \%$ yang akan direkrut apabila pembangunan usaha akomodasi pariwisata tersebut sudah selesai di bangun dan siap di operasikan. Serta, dalam proses pembangunan tersebut pihak swasta akan melibatkan pemborong atau tukang bangunan yang ada di Desa Teluk Bakau untuk mengerjakan pembangunan tersebut. Dalam sosialisasi tersebut tokoh masyarakat Desa Teluk Bakau mengusulkan agar tidak terjadi konflik pihak swasta bersedia memberikan ruang untuk akses masyarakat nelayan baik di darat maupun dilaut. Dalam sosialisasi tersebut pihak swasta menyetujuinya, namun pada kenyataannya sudah berjalan 3 tahun hal tersebut belum juga direalisasikan oleh pihak swasta.

Kegiatan eksplorasi wilayah pesisir pantai Desa Teluk Bakau yang dilakukan oleh pihak swasta tersebut mengagetkan masyarakat nelayan pesisir Desa Teluk Bakau serta menimbulkan berbagai persepsi dalam masyarakat nelayan, tentang kenapa Aparat Pemerintah Desa tanpa mensosialisasikan atau membicarakan terlebih dahulu dengan masyarakat setempat khususnya masyarakat yang beraktivitas sebagai nelayan, kemudian menjelaskan kepada masyarakat mengenai berbagai manfaat atau keuntungan dari pembangunan usaha akomodasi pariwisata baik untuk masyarakat nelayan maupun masyarakat yang bukan nelayan. serta menjelaskan pula bagaimana dampaknya kedepan dan seperti apa AMDAL-nya, dengan senantiasa memperhatikan seperti apa kondisi geografis, sosial-budayanya serta bagaimana kondisi ekonominya. 
Berikut wawancara dengan Kepala Desa Teluk Bakau berinsial Bapak RAM Usia 46 mengenai konflik antara masyarakat nelayan pesisir dengan pihak Aparat Pemerintah Desa yaitu sebagai berikut:

Memang dalam sosialisasi yang sudah kita lakukan tidak menyertakan seluruh masyarakat baik itu masyarakat nelayan, maupun masyarakat yang bukan nelayan, namun bukan berarti saya tidak memihak kepada masyarakat apalagi masyarakat nelayan karna saya dulu juga nelayan, tapi kalau kami mengumpulkan masyarakat akan ada perbedaan pendapat dari pihak yang pro dan kontra akhirnya akan menjadikan tujuan sosialisasi tidak akan tercapai.(wawancara dengan Kepala Desa Teluk Bakau).

Dari hasil wawancara dengan Kepala Desa Teluk Bakau diketahui bahwa, sosialisasi yang sudah diadakan sebelumnya sengaja tidak melibatkan masyarakat secara menyeluruh dengan alasan bahwa jika melibatkan masyarakat maka proses sosialisasi tidak akan berjalan sebagaimana mestinya. Menurut Kepala Desa Teluk Bakau tujuan diadakannya sosialisasi tersebut adalah untuk mengelola sumber daya alam yang ada dengan melibatkan pihak swasta, untuk menambah pendapatan desa dan itu juga akan di gunakan untuk kepentingan masyarakat Desa Teluk Bakau.

Perbedaan merupakan hal yang senantiasa ada dalam kehidupan sosial masyarakat, baik perbedaan antara individu atau kelompok dengan individu atau kelompok lainnya, begitu pula dengan perbedaan kepentingan. Salah satu faktor penyebab konfik adalah perbedaan kepentingan. Ketika dalam waktu yang bersamaan masing-masing individu atau kelompok memilki kepentingan yang berbeda. Kadang, orang dapat melakukan kegiatan yang sama, tetapi tujuannya berbeda.

Ketidakcocokan penggunaan lahan ini juga disinyalir karena Pemerintah Desa Teluk Bakau tidak pernah melakukan kegiatan sosialisasi kepada masyarakat khususnya masyarakat nelayan pesisir, sehingga melahirkan persepsi masyarakat bahwa ada kemungkinan kepentingan pribadi dan kelompok dari pemberian rekomendasi pembangunan usaha akomodasi pariwisata di Desa Teluk Bakau tersebut. Kondisi inilah yang di dalamnya berisi banyak potensi konflik yang sifatnya tersembunyi, atau bisa dikatakan konflik yang terjadi antara kelompok masyarakat nelayan pesisir dengan pihak Aparat Pemerintah Desa Teluk Bakau yang saat ini terjadi adalah konflik laten.

\section{KESIMPULAN}

Adanya perbedaan kepentingan terhadap penggunaan lahan melatarbelakangi munculnya konflik antara masyarakat nelayan pesisir dengan pihak aparat pemerintah desa yang sifatnya tersembunyi, atau bisa dikatakan konflik yang terjadi antara kelompok masyarakat nelayan pesisir dengan pihak Aparat Pemerintah Desa Teluk Bakau yang saat ini terjadi adalah konflik laten. Konflik yang terjadi antara kelompok masyarakat nelayan pesisir dengan pihak swasta adalah konflik manifest. Bentuk dari konflik manifest itu sendiri yaitu pergerakan masyarakat nelayan pesisir dalam bentuk aksi demontrasi terhadap pihak swasta yang bertujuan untuk menuntut agar aktivitas pembangunan usaha akomodasi pariwisata segera dihentikan. Sedangkan antar sesama masyarakat nelayan pesisir tidak adanya pertentangan atau perbedaan kepentingan yang berpotensi konflik antar sesama masyarakat nelayan pesisir. Namun, konflik yang selalu terjadi di dalam lingkungan masyarakat nelayan pesisir adalah konflik antara masyarakat nelayan pesisir dengan masyarakat yang bukan nelayan dan bukan pula masyarakat yang berdomisili di Desa Teluk Bakau yang hanya sebatas hobi untuk ke laut di saat musim ikan banyak. Konflik dalam hal ini adalah konflik agraria (fishing ground), atau konflik perebutan wilayah tangkap yaitu konflik antar nelayan dengan pihak bukan nelayan seperti masyarakat yang menjadi nelayan dadakan yang berbeda domisilinya akibat musim ikan dan sering terjadi kesalahpahaman akibat perebutan wilayah tangkap. 


\section{DAFTAR PUSTAKA}

Furi, D.R. 2007. Implikasi Konversi Lahan Terhadap Aksesibilitas Lahan dan Kesejahteraan Masyarakat Desa. Skripsi. Bogor: Institut Pertanian Bogor.

Hendropriyono, AM. 2013. Dari Terorisme sampai Konflik TNI-PolriRenungan dan Refleksi Menjaga Keutuhan NKRI. Jakarta. PT Kompas Media Nusantara.

Imron, M. 2003. "Kemiskinan dalam Masyarakat Nelayan" dalam Jurnal masyarakat dan budaya. PMB-LIPI. Jalaluddin.2002. Teknologi Pendidikan. Raja Grafindo Persada. Jakarta.

Kusnadi, 2002. Konflik Sosial Nelayan, Kemiskinan dan Perebutan Sumberdaya Perikanan. LKIS. Yogyakarta.

Mishabul Munir. 2008. Pengaruh Konversi Lahan Pertanian Terhadap Tingkat Kesejahteraan Rumah tangga Petani. Skripsi. Program Sarjana. Institut Pertanian

Bogor. Bogor. Razak, Zulkifli, 2017. Perkembangan Teori Sosial (Menyongsong Era Postmoderinisme). Makassar: CV SAH MEDIA

Sastrawidjaya, 2002. Nelayan Nusantara. Pusat Riset Pengolahan Produk Sosial Ekonomi Kelautan dan Perikanan. Jakarta.

Sugiyono, 2013. Metode Penelitian Kuantitatif Kualitatif dan R\&D. Bandung : Alfabeta, cv.

Susan, Novri. 2009. Pengantar Sosiologi Konflik. Jakarta: Prenada Media Group. Tejoyuwono Notohadiprawiro. 2006. dalam Artikel "Kemampuan dan Kesesuaian lahan : Pengertian dan Penerapannya".

\section{DOKUMEN:}

"Instruksi Presiden Nomor 9 Tahun 1969 Tentang Pedoman Pembinaan Pengembangan Kepariwisataan Nasional". 1969.

Undang-Undang Nomor 6 Tahun 2014 Tentang Desa, Lembaran Negara Republik Indonesia Tahun 2014 Nomor 7, Tambahan Lembaran Negara Nomor 5495. 